\title{
PROFIL KEMAMPUAN MAHASISWA DALAM MEMECAHKAN MASALAH MATEMATIKA DISKRIT DITINJAU DARI KECERDASAN GANDA (MULTIPLE INTELLIGENCES)
}

\author{
Erlin Ladyawati \\ Program Studi Pendidikan Matematika, Fakultas Keguruan dan Ilmu Pendidikan, \\ Universitas PGRI Adi Buana Surabaya \\ erlin.evaluasi@gmail.com
}

\begin{abstract}
Abstrak
Dengan penguasaan IPTEK yang baik, mahasiswa diharapkan memiliki kemampuan bersaing di masyarakat dan mampu menerapkan ilmunya untuk memecahkan berbagai masalah. Begitu juga dalam bidang pendidikan. Jika mahasiswa dapat menyelesaikan permasalahan yang dihadapinya, maka kemampuan mahasiswa tersebut akan menjadi berkembang. Rumusan masalah dalam penelitian ini adalah bagaimana profil mahasiswa dengan kecerdasan logis-matematis dan kecerdasan visual-spasial dalam memecahkan masalah Matematika Diskrit?. Penelitian ini merupakan penelitian deskriptif kualitatif. Subjek dari penelitian ini adalah mahasiswa Program Studi Matematika. Pada penelitian ini mahasiswa terlebih dahulu diberi daftar periksa inteligensi, kemudian daftar periksa inteligensi tersebut dianalisis untuk pengambilan sampel dari 2 jenis kecerdasan yang dominan yaitu kecerdasan logis-matematis dan kecerdasan visualspasial. Kemudian sampel dari masing-masing kecerdasan ganda (multiple intelligences) tersebut diberi tes pemecahan masalah. Sampel diberi tes pemecahan masalah dilanjutkan dengan wawancara kemudian hasilnya dianalisis secara mendalam berdasarkan langkah-langkah pemecahan masalah Berry Beyer. Dari hasil analisis data diperoleh kesimpulan bahwa pada mahasiswa dengan kecerdasan logis-matematis untuk aspek merumuskan masalah atau soal, mengembangkan jawaban sementara, dan menguji jawaban sementara termasuk kategori baik. Sedangkan pada aspek mengembangkan dan mengambil kesimpulan dan menerapkan kesimpulan pada data atau pengalaman baru mahasiswa dengan kecerdasan ini termasuk kategori cukup baik. Sehingga secara keseluruhan sampel mahasiswa dengan kecerdasan logis-matematis memliki kategori yang baik dalam memecahkan masalah Matematika Diskrit. Pada mahasiswa dengan kecerdasan visual-spasial, untuk aspek merumuskan masalah atau soal, aspek mengembangkan jawaban sementara, dan aspek menguji jawaban sementara, sampel termasuk kategori cukup baik. Sedangkan pada aspek mengembangkan dan mengambil kesimpulan, dan menerapkan kesimpulan pada data atau pengalaman baru termasuk kategori kurang baik. Sehingga secara keseluruhan sampel mahasiswa dengan kecerdasan visual-spasial memliki kategori yang cukup baik dalam memecahkan masalah Matematika Diskrit.
\end{abstract}

Kata Kunci : Pemecahan Masalah, Multiple Intellegencies, Kecerdasan Logis-Matematis, Kecerdasan Visual-Spasial

\section{PENDAHULUAN}

Pada dasarnya, pendidikan merupakan proses pengembangan potensi individu. Melalui pendidikan, potensi yang dimiliki oleh individu akan diubah menjadi kompetensi. Kompetensi menggambarkan kemampuan dan kecakapan individu dalam melaksanakan suatu tugas. Tugas dosen dalam hal ini adalah memfasilitasi mahasiswa sebagai individu agar dapat mengembangkan potensi yang dimiliki menjadi kompetensi sesuai dengan cita-citanya. Oleh karena itu, program pendidikan dan pembelajaran seperti yang berlangsung saat ini harus lebih berorientasi kepada mahasiswa. Jika mahasiswa dapat menyelesaikan permasalahan yang dihadapinya, maka kemampuan mahasiswa tersebut akan menjadi berkembang. Semakin banyak cara yang bisa dilakukan oleh mahasiswa untuk menyelesaikan permasalahan yang dihadapinya, maka semakin berkembang pula keterampilan dan kemampuan berpikirnya.
Seringkali, cara pemecahan masalah setiap mahasiswa berbeda sesuai karakteristik masing-masing. Pemecahan masalah melibatkan proses berpikir mahasiswa secara optimal. Proses berpikir pada mahasiswa tidak mudah untuk diamati. Oleh karena itu, perlu adanya penghargaan atas setiap cara menyelesaikan suatu masalah.

Howard Gardner memperkenalkan sekaligus mempromosikan hasil penelitian Project Zero di Amerika yang berkaitan dengan kecerdasan ganda (multiple intelligences). Hasil penelitiannya menunjukkan bahwa tidak ada satuan kegiatan manusia yang hanya menggunakan satu macam kecerdasan. Pendekatan Gadner lebih berorientasi pada bagaimana pikiran manusia mengolah, menggunakan, dan menguasai lingkungan. Pokok-pokok pikiran yang dikemukakan Gardner adalah; 1) Manusia mempunyai kemampuan meningkatkan dan 
memperkuat kecerdasannya, 2) Kecerdasan selain dapat berubah dapat pula diajarkan kepada orang lain, 3) Kecerdasan merupakan realitas majemuk yang muncul di bagian-bagian yang berbeda pada sistim otak atau pikiran manusia, 4) Pada tingkat tertentu, kecerdasan ini merupakan suatu kesatuan yang utuh. Artinya, dalam memecahkan masalah tertentu, seluruh kecerdasan manusia bekerja bersama-sama, kompak, dan terpadu. Kecerdasan yang terkuat cenderung "memimpin"/"melatih" kecerdasan lainnya yang lebih lemah. Berdasarkan latar belakang di atas mendorong peneliti untuk mengadakan penelitian yang berjudul profil kemampuan mahasiswa dalam memecahkan masalah Matematika Diskrit ditinjau dari kecerdasan ganda (multiple intelligences).

Secara operasional rumusan masalah penelitian ini dijabarkan dalam bentuk pertanyaan penelitian sebagai berikut:

1. Bagaimana profil mahasiswa dengan kecerdasan logis-matematis dalam memecahkan masalah Matematika Diskrit?

2. Bagaimana profil mahasiswa dengan kecerdasan visual-spasial dalam memecahkan masalah Matematika Diskrit?

\section{Pengertian Masalah Matematika}

Masalah adalah suatu hambatan, kesulitan atau tantangan, atau situasi yang membutuhkan solusi atau pemecahan. Suatu soal atau pertanyaan dapat/merupakan masalah hanya jika pertanyaan itu menunjukkan adanya suatu tantangan (challenge) yang tidak dapat dipecahkan oleh suatu prosedur rutin (routine procedure) yang sudah diketahui si pelaku.

Jika mengacu pada dua pengertian masalah di atas, beberapa ciri suatu pertanyaan, soal ataupun fenomena dikatakan sebagai masalah:

1. Menantang bagi seseorang yang menghadapi masalah tersebut.

2. Memerlukan usaha untuk memecahkannya.

3. Sangat butuh untuk dipecahkan bagi yang menghadapi masalah tersebut.

\section{Pemecahan Masalah Matematika}

Menurut Hudojo (Aisyah, 2006: 5-3) pemecahan masalah adalah suatu proses yang ditempuh oleh seseorang untuk menyelesaikan masalah yang dihadapinya sampai masalah itu tidak lagi menjadi masalah baginya.

Pemecahan masalah secara umum dapat dipelajari di kelas, sehingga mahasiswa dapat mengerti proses menyelesaikan masalah. Hal ini sesuai dengan yang dikemukakan Hudojo menyatakan bahwa di dalam menyelesaikan masalah, mahasiswa diharapkan memahami proses penyelesaian masalah tersebut dan menjadi terampil di dalam memilih dan mengidentifikasi kondisi dan konsep yang relevan, mencari generalisasi, merumuskan rencana penyelesaian, dan mengorganisasikan keterampilan yang telah dimiliki sebelumnya.

\section{Kemampuan Pemecahan Masalah Matematika}

Pandangan bahwa kemampuan menyelesaikan masalah merupakan tujuan umum pengajaran matematika, mengandung pengertian bahwa matematika dapat membantu dalam memecahkan persoalan baik dalam pelajaran lain maupun dalam kehidupan sehari-hari. Oleh karenanya kemampuan pemecahan masalah menjadi tujuan umum pembelajaran matematika.

Kemampuan pemecahan masalah merupakan kompetensi dalam kurikulum matematika yang harus dimiliki mahasiswa. Dalam pemecahan masalah mahasiswa dimungkinkan memperoleh pengalaman menggunakan pengetahuan dan keterampilan yang dimilikinya untuk menyelesaikan masalah yang bersifat non rutin. Melalui kegiatan pemecahan masalah, aspekaspek penting dalam pembelajaran matematika seperti penerapan aturan pada masalah non rutin, penemuan pola, penggeneralisasian, komunikasi matematika dan lain-lain dapat dikembangkan dengan baik.

Beberapa alasan soal-soal tipe pemecahan masalah diberikan kepada hamahasiswa adalah:

1. Dapat menimbulkan keingintahuan dan adanya motivasi, menumbuhkan sifat kreatif.

2. Di samping memiliki pengetahuan dan keterampilan (berhitung dan lain-lain), disyaratkan adanya kemampuan untuk terampil membaca dan membuat pernyataan yang benar.

3. Dapat menimbulkan jawaban yang asli, baru, khas, dan beraneka ragam, serta dapat menambah pengetahuan baru.

4. Dapat meningkatkan aplikasi dari ilmu pengetahuan yang sudah diperolehnya.

5. Mengajak mahasiswa memiliki prosedur pemecahan masalah, mampu membuat analisis dan sintesis, dan dituntut untuk membuat evaluasi tehadap hasil pemecahannya.

6. Merupakan kegiatan yang penting bagi mahasiswa yang melibatkan bukan saja satu bidang studi tetapi mungkin bidang atau pelajaran lain.

Pemecahan masalah juga dapat membantu mahasiswa mempelajari fakta-fakta, konsep, prinsip matematika dengan mengilustrasikan obyek matematika dan realisasinya. Pemecahan masalah merupakan aktifitas yang memberikan tantangan bagi kebanyakan mahasiswa serta dapat memotivasi mahasiswa untuk belajar matematika. 


\section{Multiple Intellegences}

Selama ini kita mengenal uji kecerdasan melalui tes IQ, padahal pada situasi yang lebih kompleks dan nyata misalnya, orang yang ber-IQ tinggi belum tentu sukses dalam menjalin hubungan dengan teman-teman lain atau sukses dalam bermain musik ataupun bidang lain. Menurut Gardner, hal ini karena pengukuran IQ hanya ditekankan pada kecerdasan logika matematika dan linguistik saja dan kurang memperhatikan kecerdasan-kecerdasan yang lain.

Pada awal penelitiannya, Gardner mengumpulkan beberapa kemampuan manusia yang dapat dimasukkan dalam pengertiannya tentang kecerdasan. Setelah semua kemampuan tersebut dianalisis secara teliti akhirnya dapat diterima bahwa pada diri manusia terdapat tujuh kecerdasan. Pada bukunya Intelligence Reframed ia menambahkan 2 kecerdasan baru, yaitu kecerdasan lingkungan/naturalis (naturalist intelligence) dan kecerdasan eksistensial (existential intelligence). Kesembilan kecerdasan yang diterima yaitu:

1. kecerdasan linguistic (linguistic intelligence),

2. kecerdasan logika matematika (logical mathematical intelligence),

3. kecerdasan visual spasial (visual spatial intelligence),

4. kecerdasan kinestetik (kinesthetic intelligence),

5. kecerdasan musikal (musical intelligence),

6. kecerdasan interpersonal (interpersonal intelligence),

7. kecerdasan intrapersonal intelligence),

(intrapersonal

8. kecerdasan naturalis(naturalist intelligence), dan

9. kecerdasan eksistensial (existensial intelligence)

Dari sembilan jenis kecerdasan di atas, maka peneliti hanya akan meneliti atau mengidentifikasi 2 jenis kecerdasan saja, yaitu: kecerdasan logika matematika (logical mathematical intelligence), dan kecerdasan visual spasial (visual spatial intelligence). Kecerdasan logika matematika(logical-mathematical intelligence), dapat digambarkan dengan aktivitas menghitung, membuat kategorisasi atau penggolongan, membuat pemikiran ilmiah dengan proses ilmiah, membuat analogi dan sebagainya. Sedangkan kecerdasan visual spasial (spatialvisual intelligence), dapat digambarkan dengan aktivitas visualisasi materi dengan membuat sketsa, gambar, simbol grafik, dan sebagainya.

\section{Hubungan Kemampuan Pemecahan Masalah dengan Kecerdasan Ganda (Multiple Intelligences)}

Kehadiran teori kecerdasan ganda (multiple intelligences) menjadi bagian dari usaha Gardner untuk memperluas lingkup potensi manusia melalui batas nilai IQ. Gardner sangat serius mempertanyakan akan keabsahan penilaian kecerdasan individu melalui tes-tes yang dilakukan di luar lingkungan belajar alamiah. Dia juga menggugat penilaian kecerdasan yang dilakukan dengan meminta seseorang melakukan tindakan terisolasi yang belum pernah dia lakukan sebelumnya. Kecerdasan itu berkaitan dengan kapasitas untuk memecahkan masalah dan menciptakan produk di lingkungan yang kondusif dan alamiah. Pendapat ini menggariskan bahwa potensi dasar manusia harus dipersepsi dari dimensi dinamisnya daripada dimensi statisnya. Bukan sebatas berapa tingkat kecerdasan yang diperlukan untuk menyelesaikan sebuah soal matematika yang rumit, melainkan bagaimana dia memanfaatkan potensi diri dan hal-hal di luar dirinya untuk memecahkan soal itu.

\section{Subyek Penelitian}

Subyek dari penelitian ini adalah seluruh mahasiswa Program Studi Matematika Fakultas Keguruan dan Ilmu Pendidikan Universitas PGRI Adi Buana Surabaya angkatan 2013 semester 6 kelas A. Berdasarkan hasil analisis daftar periksa kecerdasan ganda (multiple intelligences) diambil 2 orang mahasiswa sebagai sampel yang mewakili kecerdasan logis-matematis dan 2 orang mahasiswa sebagai sampel yang mewakili kecerdasan visual-spasial. Sampel tersebut digunakan sebagi responden untuk wawancara.

\section{METODE}

Prosedur penelitian yang digunakan peneliti terdiri dari empat tahap, yaitu:

1. Tahap Persiapan

Kegiatan yang dilakukan pada tahap persiapan adalah:

a. Menyusun instrumen penelitian berupa daftar periksa kecerdasan ganda (multiple intelligences), soal tes untuk kemampuan pemecahan masalah matematika, dan lembar validasi instrumen.

b. Melakukan validasi terhadap instrumen penelitian. Validasi dilakukan oleh Dosen dan ahli di bidang matematika dan psikologi.

2. Tahap Pelaksanaan

Kegiatan yang dilakukan pada tahap pelaksanaan adalah:

a. Memberikan daftar periksa kecerdasan ganda (multiple intelligences) kepada subjek penelitian dan menganalisis hasilnya untuk mengelompokkan kecerdasan ganda (multiple intelligences) yang dimiliki oleh subjek penelitian. Dari hasil analisis tersebut diambil 2 orang mahasiswa yang memiliki skor kecerdasan logis-matematis lebih dominan dan 2 orang mahasiswa yang memiliki skor kecerdasan visualspasial lebih dominan untuk menyelesaikan soal 
tes kemampuan pemecahan masalah matematika dan dilanjutkan dengan wawancara.

b. Memberikan soal tes kemampuan pemecahan masalah Matematika Diskrit kepada masingmasing sampel, kemudian melakukan wawancara setelah subjek memecahkan soal yang diberikan. Tujuan wawancara untuk mengetahui proses yang dilakukan masing-masing subjek penelitian dalam memecahkan masalah Matematika Diskrit yang diberikan oleh peneliti.

3. Tahap Analisa Data

Kegiatan yang dilakukan pada tahap analisis data adalah:

a. Mereduksi data yaitu melakukan pemilihan, menggolongkan dan membuang data yang tidak perlu serta mengorganisasikan data mentah yang diperoleh langsung dari lapangan.

b. Pemaparan data yaitu mengklasifasi dan mengidentifikasi data agar terorganisir dan terkategori dengan baik sehingga memungkinkan penarikan kesimpulan dan tindakan.

c. Analisis data yaitu menganalisis hasil penyelesaian soal tes pemecahan masalah Matematika Diskrit dan wawancara agar peneliti dapat mendeskripsikan profil kemampuan mahasiswa dalam memecahkan masalah Matematika Diskrit ditinjau dari kecerdasan logismatematis dan kecerdasan visual-spasial yang dimiliki oleh masing-masing sampel penelitian.

d. Penarikan kesimpulan dilakukan setelah analisis data. Penarikan kesimpulan bertujuan untuk merumuskan profil kemampuan subjek dengan kecerdasan logis-matematis dan kecerdasan visual-spasial dalam memecahkan masalah matematika.

e. Penulisan Laporan Penelitian

\section{HASIL DAN PEMBAHASAN}

\section{Data Tes Kecerdasan Ganda (Multiple Intelligences)}

Berikut ini adalah daftar nama calon subjek yang memiliki kecerdasan logis-matematis dan kecerdasan visual-spasial yang dapat dilihat pada tabel 1 .

Tabel 1. Daftar Calon Sampel dengan Kecerdasan LogisMatematis dan Visual-Spasial

\begin{tabular}{|l|c|c|l|}
\hline No. & Nama & Skor Maksimal & $\begin{array}{l}\text { Jenis } \\
\text { Kecerdasan }\end{array}$ \\
\hline 1 & A & 10 & \multirow{1}{*}{ Logis - } \\
\hline 2 & B & 9 & Matematis \\
\hline 3 & C & 10 & \\
\hline 4 & D & 10 & \\
\hline 5 & E & 9 & 8 \\
\hline 6 & F & \multicolumn{2}{|c|}{} \\
\hline
\end{tabular}

\begin{tabular}{|l|c|c|l|}
\hline No. & Nama & Skor Maksimal & $\begin{array}{l}\text { Jenis } \\
\text { Kecerdasan }\end{array}$ \\
\hline 7 & G & 8 & \multirow{1}{*}{ Visual - } \\
\hline 8 & H & 9 & Spasial \\
\hline 9 & I & 10 & \\
\hline 10 & J & 10 & \\
\hline 11 & K & 9 & 10 \\
\hline 12 & L & \multicolumn{1}{|c|}{} \\
\hline
\end{tabular}

Dari data daftar calon sampel yang memiliki kecerdasan logis-matematis dan kecerdasan visual spasial pada tabel 1 di atas maka dipilih 2 mahasiswa dari masingmasing kecerdasan tersebut secara acak. Adapun rincian masing-masing sampel penelitian yang terpilih, disajikan pada tabel 2 berikut ini.

Tabel 2. Daftar Sampel Penelitian yang Terpilih

\begin{tabular}{|c|l|c|c|}
\hline No. & Nama & Kode & $\begin{array}{c}\text { Jenis } \\
\text { Kecerdasan }\end{array}$ \\
\hline 1. & E & LM-1 & $\begin{array}{c}\text { Logis - } \\
\text { Matematis }\end{array}$ \\
\hline 2. & F & LM-2 & Visual - \\
\hline 1. & H & VS-1 & Spasial \\
\hline 2. & L & VS-2 & \\
\hline
\end{tabular}

Berdasarkan tabel 2 diperoleh sampel penelitian yang mewakili kecerdasan logis-matematis dan kecerdasan visual-spasial. Dari sampel penelitian yang terpilih selanjutnya akan diberikan soal tes pemecahan masalah Matematika Diskrit untuk mengetahui profil mahasiswa dengan kecerdasan logis-matematis dan kecerdasan visualspasial dalam memecahkan masalah matematika.

\section{Analisis Tes Pemecahan Masalah}

Pemberian tes pemecahan masalah matematika dilakukan pada sampel penelitian dengan kecerdasan logis-matematis dan kecerdasan visual-spasial yang terpilih yang dapat dilihat pada tabel 2. Pada pengambilan data pemecahan masalah Matematika Diskrit, sampel diberikan soal tes pemecahan masalah dan mengerjakannya selama 90 menit kemudian baru diwawancarai. Adapun langkahlangkah yang diamati adalah lima langkah pemecahan masalah Berry Beyer yaitu merumuskan masalah atau soal, mengembangkan jawaban sementara, menguji jawaban sementara, mengembangkan dan mengambil kesimpulan, dan menerapkan kesimpulan pada data atau pengalaman baru.

a. Analisis Data terhadap Mahasiswa dengan Kecerdasan Logis-Matematis

Hasil analisis tes pemecahan masalah Matematika Diskrit pada kecerdasan logis-matematis berdasarkan langkah Berry Beyer untuk sampel pertama (LM-1) dapat dilihat pada tabel berikut ini : 
Tabel 3.Kemampuan Pemecahan Masalah Matematika Diskrit Sampel LM-1

\begin{tabular}{|c|c|c|c|c|c|}
\hline \multirow{2}{*}{$\begin{array}{c}\text { Aspek } \\
\text { Pemecahan } \\
\text { Masalah }\end{array}$} & \multicolumn{5}{|c|}{ Nomer soal } \\
\hline & 1 & 2 & 3 & 4 & 5 \\
\hline $\begin{array}{l}\text { Merumuskan } \\
\text { masalah atau } \\
\text { soal }\end{array}$ & Baik & Baik & Baik & $\begin{array}{l}\text { Bai } \\
\mathrm{k}\end{array}$ & Baik \\
\hline $\begin{array}{l}\text { Mengemban } \\
\text { gkan } \\
\text { jawaban } \\
\text { sementara }\end{array}$ & Baik & Baik & Baik & $\begin{array}{l}\text { Bai } \\
\mathrm{k}\end{array}$ & Baik \\
\hline $\begin{array}{l}\text { Menguji } \\
\text { jawaban } \\
\text { sementara }\end{array}$ & $\begin{array}{l}\text { Cuk } \\
\text { up } \\
\text { Baik }\end{array}$ & $\begin{array}{l}\text { Cuk } \\
\text { up } \\
\text { Baik }\end{array}$ & Baik & $\begin{array}{l}\text { Bai } \\
k\end{array}$ & Baik \\
\hline $\begin{array}{l}\text { Mengemban } \\
\text { gkan dan } \\
\text { mengambil } \\
\text { kesimpulan }\end{array}$ & $\begin{array}{l}\text { Cuk } \\
\text { up } \\
\text { Baik }\end{array}$ & Baik & Baik & $\begin{array}{l}\text { Bai } \\
\mathrm{k}\end{array}$ & $\begin{array}{l}\text { Cuk } \\
\text { up } \\
\text { Baik }\end{array}$ \\
\hline $\begin{array}{l}\text { Menerapkan } \\
\text { kesimpulan } \\
\text { pada data } \\
\text { atau } \\
\text { pengalaman } \\
\text { baru. }\end{array}$ & $\begin{array}{l}\text { Cuk } \\
\text { up } \\
\text { Baik }\end{array}$ & $\begin{array}{l}\text { Cuk } \\
\text { up } \\
\text { Baik }\end{array}$ & $\begin{array}{l}\text { Cuk } \\
\text { up } \\
\text { Baik }\end{array}$ & $\begin{array}{l}\text { Bai } \\
k\end{array}$ & $\begin{array}{l}\text { Cuk } \\
\text { up } \\
\text { Baik }\end{array}$ \\
\hline
\end{tabular}

Sedangkan hasil analisis tes pemecahan masalah Matematika Diskrit pada kecerdasan logis-matematis berdasarkan langkah Berry Beyer untuk sampel kedua (LM-2) dapat dilihat pada tabel berikut ini:

Tabel 4. Kemampuan Pemecahan Masalah Matematika Diskrit Sampel LM-2

\begin{tabular}{|c|c|c|c|c|c|}
\hline \multirow{2}{*}{$\begin{array}{c}\text { Aspek } \\
\text { Pemecahan } \\
\text { Masalah } \\
\end{array}$} & \multicolumn{5}{|c|}{ Nomer soal } \\
\hline & 1 & 2 & 3 & & 5 \\
\hline $\begin{array}{l}\text { Merumuskan } \\
\text { masalah atau } \\
\text { soal }\end{array}$ & Baik & Baik & Baik & Baik & Baik \\
\hline $\begin{array}{l}\text { Mengembang } \\
\text { kan jawaban } \\
\text { sementara }\end{array}$ & Baik & Baik & Baik & $\begin{array}{l}\text { Cuk } \\
\text { up } \\
\text { Baik }\end{array}$ & Baik \\
\hline $\begin{array}{l}\text { Menguji } \\
\text { jawaban } \\
\text { sementara } \\
\end{array}$ & Baik & Baik & Baik & $\begin{array}{l}\text { Cuk } \\
\text { up } \\
\text { Baik } \\
\end{array}$ & $\begin{array}{l}\text { Cuk } \\
\text { up } \\
\text { Baik }\end{array}$ \\
\hline $\begin{array}{l}\text { Mengembang } \\
\text { kan dan } \\
\text { mengambil } \\
\text { kesimpulan }\end{array}$ & Baik & Baik & $\begin{array}{l}\text { Cuk } \\
\text { up } \\
\text { Baik }\end{array}$ & Baik & Baik \\
\hline $\begin{array}{l}\text { Menerapkan } \\
\text { kesimpulan } \\
\text { pada data } \\
\text { atau } \\
\text { pengalaman } \\
\text { baru. }\end{array}$ & $\begin{array}{l}\text { Cuk } \\
\text { up } \\
\text { Baik }\end{array}$ & $\begin{array}{l}\text { Cuk } \\
\text { up } \\
\text { Baik }\end{array}$ & $\begin{array}{l}\text { Cuk } \\
\text { up } \\
\text { Baik }\end{array}$ & $\begin{array}{l}\text { Cuk } \\
\text { up } \\
\text { Baik }\end{array}$ & $\begin{array}{l}\text { Cuk } \\
\text { up } \\
\text { Baik }\end{array}$ \\
\hline
\end{tabular}

b. Analisis Data terhadap Mahasiswa dengan Kecerdasan Visual-spasial

Analisis profil mahasiswa dengan kecerdasan visualspasial dalam memecahkan masalah matematika berdasarkan langkah Berry Beyer untuk sampel pertama (VS-1) dapat dilihat pada tabel berikut ini :

Tabel 5. Kemampuan Pemecahan Masalah Matematika Diskrit Sampel VS-1

\begin{tabular}{|c|c|c|c|c|c|}
\hline \multirow{2}{*}{$\begin{array}{c}\text { Aspek } \\
\text { Pemecahan } \\
\text { Masalah }\end{array}$} & \multicolumn{5}{|c|}{ Nomer soal } \\
\hline & 1 & 2 & 3 & 4 & 5 \\
\hline $\begin{array}{l}\text { Merumuskan } \\
\text { masalah atau soal }\end{array}$ & $\begin{array}{l}\text { Cukup } \\
\text { Baik }\end{array}$ & $\begin{array}{c}\text { Cukup } \\
\text { Baik }\end{array}$ & Baik & $\begin{array}{l}\text { Cukup } \\
\text { Baik }\end{array}$ & $\begin{array}{l}\text { Cukup } \\
\text { Baik }\end{array}$ \\
\hline $\begin{array}{l}\text { Mengembangkan } \\
\text { jawaban } \\
\text { sementara }\end{array}$ & $\begin{array}{l}\text { Cukup } \\
\text { Baik }\end{array}$ & Baik & Baik & $\begin{array}{l}\text { Cukup } \\
\text { Baik }\end{array}$ & $\begin{array}{l}\text { Cukup } \\
\text { Baik }\end{array}$ \\
\hline $\begin{array}{l}\text { Menguji jawaban } \\
\text { sementara }\end{array}$ & $\begin{array}{l}\text { Cukup } \\
\text { Baik }\end{array}$ & Baik & $\begin{array}{l}\text { Cukup } \\
\text { Baik }\end{array}$ & $\begin{array}{l}\text { Cukup } \\
\text { Baik }\end{array}$ & $\begin{array}{c}\text { Cukup } \\
\text { Baik }\end{array}$ \\
\hline $\begin{array}{l}\text { Mengembangkan } \\
\text { dan mengambil } \\
\text { kesimpulan }\end{array}$ & $\begin{array}{c}\text { Kurang } \\
\text { Baik }\end{array}$ & $\begin{array}{c}\text { Kurang } \\
\text { Baik }\end{array}$ & $\begin{array}{c}\text { Kurang } \\
\text { Baik }\end{array}$ & Baik & Baik \\
\hline $\begin{array}{l}\text { Menerapkan } \\
\text { kesimpulan pada } \\
\text { data atau } \\
\text { pengalaman baru. }\end{array}$ & $\begin{array}{c}\text { Kurang } \\
\text { Baik }\end{array}$ & $\begin{array}{c}\text { Kurang } \\
\text { Baik }\end{array}$ & $\begin{array}{c}\text { Kurang } \\
\text { Baik }\end{array}$ & $\begin{array}{c}\text { Kurang } \\
\text { Baik }\end{array}$ & $\begin{array}{c}\text { Cukup } \\
\text { Baik }\end{array}$ \\
\hline
\end{tabular}

Sedangkan hasil analisis tes pemecahan masalah Matematika Diskrit pada kecerdasan visual-spasial berdasarkan langkah Berry Beyer untuk sampel kedua (VS2) dapat dilihat pada tabel berikut ini:

Tabel 6. Kemampuan Pemecahan Masalah Matematika Diskrit Sampel VS-2

\begin{tabular}{|c|c|c|c|c|c|}
\hline \multirow{2}{*}{$\begin{array}{c}\text { Aspek } \\
\text { Pemecahan } \\
\text { Masalah }\end{array}$} & \multicolumn{5}{|c|}{ Nomer soal } \\
\hline & 1 & 2 & 3 & 4 & 5 \\
\hline $\begin{array}{l}\text { Merumuska } \\
\mathrm{n} \text { masalah } \\
\text { atau soal }\end{array}$ & $\begin{array}{l}\text { Cuku } \\
\mathrm{p} \\
\text { Baik }\end{array}$ & $\begin{array}{l}\text { Cuku } \\
\mathrm{p} \\
\text { Baik }\end{array}$ & Baik & $\begin{array}{l}\text { Cuku } \\
\mathrm{p} \\
\text { Baik }\end{array}$ & $\begin{array}{l}\text { Cuk } \\
\text { up } \\
\text { Baik }\end{array}$ \\
\hline $\begin{array}{l}\text { Mengemban } \\
\text { gkan } \\
\text { jawaban } \\
\text { sementara }\end{array}$ & $\begin{array}{l}\text { Cuku } \\
\mathrm{p} \\
\text { Baik }\end{array}$ & Baik & Baik & $\begin{array}{l}\text { Cuku } \\
\mathrm{p} \\
\text { Baik }\end{array}$ & $\begin{array}{l}\text { Cuk } \\
\text { up } \\
\text { Baik }\end{array}$ \\
\hline $\begin{array}{l}\text { Menguji } \\
\text { jawaban } \\
\text { sementara }\end{array}$ & $\begin{array}{l}\text { Cuku } \\
\mathrm{p} \\
\text { Baik }\end{array}$ & Baik & $\begin{array}{l}\text { Cuku } \\
\mathrm{p} \\
\text { Baik }\end{array}$ & $\begin{array}{l}\text { Cuku } \\
\mathrm{p} \\
\text { Baik }\end{array}$ & $\begin{array}{l}\text { Cuk } \\
\text { up } \\
\text { Baik }\end{array}$ \\
\hline $\begin{array}{l}\text { Mengemban } \\
\text { gkan dan } \\
\text { mengambil } \\
\text { kesimpulan }\end{array}$ & $\begin{array}{l}\text { Kura } \\
\text { ng } \\
\text { Baik }\end{array}$ & $\begin{array}{l}\text { Kura } \\
\text { ng } \\
\text { Baik }\end{array}$ & $\begin{array}{l}\text { Kura } \\
\text { ng } \\
\text { Baik }\end{array}$ & $\begin{array}{l}\text { Cuku } \\
\mathrm{p} \\
\text { Baik }\end{array}$ & Baik \\
\hline $\begin{array}{l}\text { Menerapkan } \\
\text { kesimpulan } \\
\text { pada data } \\
\text { atau }\end{array}$ & $\begin{array}{l}\text { Kura } \\
\text { ng } \\
\text { Baik }\end{array}$ & $\begin{array}{l}\text { Kura } \\
\text { ng } \\
\text { Baik }\end{array}$ & $\begin{array}{l}\text { Cuku } \\
\mathrm{p} \\
\text { Baik }\end{array}$ & $\begin{array}{l}\text { Kura } \\
\text { ng } \\
\text { Baik }\end{array}$ & $\begin{array}{l}\text { Cuk } \\
\text { up } \\
\text { Baik }\end{array}$ \\
\hline
\end{tabular}




\begin{tabular}{|c|c|c|c|c|c|}
\hline \multirow{2}{*}{$\begin{array}{c}\text { Aspek } \\
\text { Pemecahan } \\
\text { Masalah }\end{array}$} & \multicolumn{5}{|c|}{ Nomer soal } \\
\cline { 2 - 6 } & $\mathbf{1}$ & $\mathbf{2}$ & $\mathbf{3}$ & $\mathbf{4}$ & $\mathbf{5}$ \\
\hline $\begin{array}{c}\text { pengalaman } \\
\text { baru. }\end{array}$ & & & & & \\
\hline
\end{tabular}

Setelah didapatkan data tentang kategori pada masing-masing sampel untuk kecerdasan logis-matematis dan kecerdasan visual-spasial, maka dilanjutkan dengan wawancara. Wawancara sangat penting dilakukan dengan tujuan untuk mengetahui dan menangkap secara langsung seluruh informasi dari setiap subjek penelitian dalam hal ini wawancara bertujuan untuk mengetahui pemahaman dan alur berfikir dalam hal memecahkan masalah matematika. Wawancara dilakukan terhadap mahasiswa yang menjadi sampel penelitian, yaitu empat siswa

\section{Pembahasan}

Berdasarkan hasil analisis dan penelitian yang diperoleh maka dapat diperoleh tentang profil mahasiswa Universitas PGRI Adi Buana Surabaya Program Studi Pendidikan Matematika Angkatan 2013 semester 6 kelas A dengan kecerdasan logis-matematis dan kecerdasan visualspasial dalam memecahkan masalah Matematika Diskrit adalah sebagai berikut:

1.Profil mahasiswa dengan kecerdasan logismatematis dalam memecahkan masalah Matematika Diskrit adalah sebagai berikut:

Dalam merumuskan masalah atau soal, mengembangkan jawaban sementara, dan menguji jawaban sementara termasuk kategori baik.

Sedangkan pada aspek mengembangkan dan mengambil kesimpulan dan menerapkan kesimpulan pada data atau pengalaman baru mahasiswa dengan kecerdasan ini termasuk kategori cukup baik. Mahasiswa dengan kecerdasan logis-matematis menyukai aktivitas menghitung. Mahasiswa dengan kecerdasan ini dapat menyelesaikan masalah secara sistematis dengan mengklasifikasi data, menganalisis data, merumuskan hipotesis, kemudian menguji kembali kesimpulan yang telah didapatkan. Sehingga, mahasiswa dengan kecerdasan logis-matematis yang tinggi akan terampil dalam memecahkan masalah matematika yang dihadapinya.

Sampel dengan kecerdasan logis-matematis, dalam aspek merumuskan masalah menuliskan beberapa hal yang diketahui dan ditanyakan pada lembar jawaban serta dapat menjelaskannya secara tepat. Dalam mengembangkan jawaban sementara, sampel dapat menentukan hubungan dari setiap data yang diketahui dalam soal. Pada aspek menguji jawaban sementara mahasiswa dengan kecerdasan ini mampu menentukan strategi yang mengarah pada penyelesaian yang benar dari masalah dengan cepat dan cermat. Kemudian pada aspek mengembangkan dan mengambil kesimpulan mereka mampu menyimpulkan penyelesaian masalah dengan tepat. Sehingga pada aspek melaksanakan langkah-langkah penyelesaikan masalah sampel termasuk kategori yang baik. Aspek selanjutnya yaitu menerapkan kesimpulan pada data atau pengalaman, sampel melakukan pengujian cukup baik dari proses maupun jawaban dan membuat generalisasi tentang hasilnya. Sehingga sampel termasuk dalam kategori baik dalam pemecahan masalah secara keseluruhan.

2.Profil mahasiswa dengan kecerdasan visualspasial dalam memecahkan masalah Matematika Diskrit adalah sebagai berikut:

Dalam aspek merumuskan masalah atau soal, aspek mengembangkan jawaban sementara, dan aspek menguji jawaban sementara, sampel termasuk kategori cukup baik. Sedangkan pada aspek mengembangkan dan mengambil kesimpulan, dan menerapkan kesimpulan pada data atau pengalaman baru termasuk kategori kurang baik. Mahasiswa dengan kecerdasan visual-spasial cenderung lebih mudah menyelesaikan soal dengan mengubah soal tersebut ke dalam bentuk grafik ataupun tabel.

Sampel penelitian yang memiliki kecerdasan visualspasial dapat menjelaskan maksud dari masalah yang diberikan. Namun dalam strategi penyelesaian, strategi yang digunakan sampel tidak dapat secara langsung menyelesaikan masalah. Sampel mengkombinasikan beberapa strategi. Walaupun bisa menyelesaikan soal dengan cukup baik, tapi memerlukan waktu penyelesaian yang sedikit lebih lama. Saat melakukan langkah-langkah penyelesaian, sampel termasuk dalam kategori cukup baik. Hal ini terlihat bahwa sampel tidak hanya mempunyai hasil penyelesaian, tetapi disertai dengan penjelasan. Setelah menyelesaikan permasalahan, sampel cenderung melakukan pengecekan pada hasil akhir saja. Sehingga sampel termasuk dalam kategori cukup baik dalam pemecahan masalah secara keseluruhan.

\section{KESIMPULAN}

Berdasarkan pembahasan yang telah diuraika diatas, didapat disimpulkan bahwa:

1. Profil mahasiswa dengan kecerdasan logis-matematis Pada aspek merumuskan masalah atau soal, mengembangkan jawaban sementara, dan menguji jawaban sementara termasuk kategori baik. Sedangkan pada aspek mengembangkan dan mengambil kesimpulan dan menerapkan kesimpulan pada data atau pengalaman baru mahasiswa dengan kecerdasan ini termasuk kategori cukup baik. Sehingga secara keseluruhan sampel mahasiswa dengan kecerdasan logis-matematis memliki kategori yang baik dalam memecahkan masalah Matematika Diskrit.

\section{Profil mahasiswa dengan kecerdasan visual-spasial}

Dalam aspek merumuskan masalah atau soal, aspek mengembangkan jawaban sementara, dan aspek menguji jawaban sementara, sampel termasuk kategori cukup baik. Sedangkan pada aspek mengembangkan dan mengambil kesimpulan, dan menerapkan kesimpulan pada data atau 
pengalaman baru termasuk kategori kurang baik. Sehingga secara keseluruhan sampel mahasiswa dengan kecerdasan visual-spasial memliki kategori yang cukup baik dalam memecahkan masalah Matematika Diskrit.

\section{DAFTAR PUSTAKA}

Amstrong, Thomas. 2013. Kecerdasan Multiple di dalam Kelas. Jakarta: Indeks.

Arikunto, Suharsimi. 2010. Prosedur Penelitian Suatu Pendekatan Praktik. Jakarta:Rineka Cipta.

2009. Dasar-Dasar Evaluasi Pendidikan. Jakarta: Bumi Aksara.

Chatib, Munif. 2012. Sekolahnya Manusia: Sekolah Berbasis Multiple Intelligences di Indonesia. Bandung: Mizan Media Utama.

Dimyati dan Mudjiono. 2006. Belajar dan Pembelajaran. Jakarta: PT Rineka Cipta

Eggen, Paul dan Don Kauchak. 2012. Strategi dan Model Pembelajaran. Jakarta: Indeks.

Jasmine, Julia.2007. Mengajar Berbasis Multiple Intelligences. Bandung : Nuansa.
Huda, Miftahul. 2013. Model-Model Pengajaran dan Pembelajaran. Yogyakarta: Pustaka Pelajar.

Kurniawan, Ricki. 2012. Pengertian Matematika Menurut Beberapa Ahli. http://masihberbagi.blogspot.com/2012/08/pengertianmatematika-menurut-beberapa.html. Diakses tanggal 04 Juli 2014 pukul 20.00.

Moleong, Lexy J. 2011. Metologi Penelitian Kualitatif. Bandung: Remaja Rosdakarya Offset.

Nisbah, Faizal. Pemecahan Masalah dalam Matematika. http://faizalnizbah.blogspot.com/2013/07/pemecah an-masalah-dalam-matematika.html. Diakses 4tanggal 4 Juli 2014 pukul 17.22.

Rachman, Eillen. 2005. Mengoptimalkan Kecerdasan Anak. Jakarta : PT Gramedia Pustaka Utama.

Suprihatiningrum, Jamil. 2013. Strategi Pembelajaran: Teori dan Aplikasi. Yogyakarta: Ar-Ruzz Media.

Thobroni, Muhammad dan Arif Mustofa. 2012. Belajar dan Pembelajaran. Jogjakarta: Ar-Ruzz Media. 